\title{
Study of the Vickers hardness and corrosion behavior of experimental Ti-Mo alloy in dental office bleaching agents
}

\author{
Estudo da dureza Vickers e comportamento de corrosão da liga experimental \\ Ti-Mo em agentes clareadores para uso em consultório
}

\author{
Maria Cristina Rosifini ALVES REZENDE ${ }^{1}$ \\ Juliana Caires FELIPE ${ }^{1}$ \\ Roberto Zenhei NAKAZATO ${ }^{2}$ \\ Conceição Aparecida Matsumoto DUTRA ${ }^{2}$ \\ André Luiz Reis RANGEL ${ }^{2}$ \\ João Pedro Justino de Oliveira LIMÍRIO ${ }^{1}$ \\ Ana Paula Rosifini ALVES CLARO
}

Estudio de la dureza Vickers y comportamiento de corrosión de la aleación experimental Ti-Mo en agentes blanqueadores para uso en consultorio

${ }^{1}$ São Paulo State University (UNESP), School of Dentistry, Araçatuba 16015-050 Araçatuba-SP, Brasil

${ }^{2}$ São Paulo State University (UNESP), School of Engineering, Guaratinguetá 12516-410 Guaratinguetá-SP, Brasil

\begin{abstract}
At present, titanium and its alloys stand out for their mechanical and biological properties. Vickers hardness and the effect of $15 \%, 22 \%$ and $35 \%$ hydrogen peroxide $\left(\mathrm{H}_{2} \mathrm{O}_{2}\right)$ on Ti-10Mo alloy corrosion were evaluated. A conventional double-walled glass cell was used for thermostatization. As reference electrode was used the $\mathrm{Ag} / \mathrm{AgCl}(\mathrm{s}) / \mathrm{KClsat}$ and as auxiliary electrode graphite stick. The work electrodes consisted of Ti-10Mo cylinders embedded in polyethylene, with electrical contact by brass wire and silver paint on one end. The electrolyte used was $\mathrm{H}_{2} \mathrm{O}_{2}$ in concentrations of $15 \%, 22 \%$ and $35 \%$ and potentiodynamic measurements were recorded. The Vickers hardness was evaluated before the treatment using Vickers penetrator under load of $1000 \mathrm{~g}$ and dwell time of $10 \mathrm{~s} /$ measurement separately. The results showed an increase in the corrosion values in direct relation with the increase of the $\mathrm{H}_{2} \mathrm{O}_{2}$ concentration. At $35 \%$ concentration, at constant current of $\sim 1.0 \mathrm{~V}$ the alloy did not passivate, characterizing high corrosion rate. At the concentrations of $15 \%$ and $22 \%$ the results showed a tendency to pseudopassivation, with release of $\mathrm{TiO}_{2}$ and part of the product of the corrosion becoming semi-adherent to the surface of the working electrode and another part passing through the middle, characterizing intermediate corrosion velocity. It was concluded that higher $\mathrm{H}_{2} \mathrm{O}_{2}$ concentrations produced higher electrochemical corrosion.
\end{abstract}

Descriptors: Titanium; Alloys; Surface Properties; Corrosion; Tooth Bleaching Agents.

\section{Resumo}

$\mathrm{Na}$ atualidade, titânio e as suas ligas se destacam por suas propriedades mecânicas e biológicas. Avaliou-se a dureza Vickers e o efeito do peróxido de hidrogênio $\left(\mathrm{H}_{2} \mathrm{O}_{2}\right)$ a $15 \%, 22 \%$ e $35 \%$ na corrosão da liga Ti-10Mo. Utilizou-se célula convencional de vidro de parede dupla para a termostatização. Como eletrodo de referência foi empregado o $\mathrm{Ag} / \mathrm{AgCl}(\mathrm{s}) / \mathrm{KCl}_{\mathrm{sat}}$ e como eletrodo auxiliar bastão de grafite. Os eletrodos de trabalho consistiram de cilindros de Ti-10Mo embutidos em polietileno, com contato elétrico por fio de latão e tinta de prata em uma das extremidades. O eletrólito utilizado foi $\mathrm{H}_{2} \mathrm{O}_{2}$ em concentração de $15 \%$, $22 \%$ e $35 \%$ e medidas potenciodinâmicas foram registradas. A dureza Vickers foi avaliada antes do tratamento utilizando penetrador Vickers sob carga de $1000 \mathrm{~g}$ e tempo de permanência de 10s/medição separada. Os resultados obtidos mostraram aumento nos valores de corrosão em relação direta com o aumento da concentração de $\mathrm{H}_{2} \mathrm{O}_{2}$. $\mathrm{Na}$ concentração de $35 \%$, em corrente constante de $\sim 1.0 \mathrm{~V}$ a liga não passivou, caracterizando alta taxa de corrosão. Nas concentrações de $15 \%$ e $22 \%$ os resultados apontaram tendência à pseudopassivação, com liberação de $\mathrm{TiO}_{2}$ e parte do produto da corrosão tornando-se semiaderente à superfície do eletrodo de trabalho e outra parte passando para o meio, caracterizando velocidade de corrosão intermediária. Concluiu-se que maiores concentrações de $\mathrm{H}_{2} \mathrm{O}_{2}$ produziram maior corrosão eletroquímica.

Descritores: Titânio; Ligas; Propriedades de Superfície; Corrosão; Clareadores Dentários.

\section{Resumen}

En la actualidad, titanio y sus aleaciones se destacan por sus propiedades mecánicas y biológicas. Se evaluó la dureza Vickers y el efecto del peróxido de hidrógeno $\left(\mathrm{H}_{2} \mathrm{O}_{2}\right)$ al 15\%, 22\% y 35\% en la corrosión de la aleación Ti-10Mo. Se utilizó una célula convencional de vidrio de doble pared para la termostatización. Como electrodo de referencia se utilizó el Ag/AgCl (s / KClsat y como electrodo auxiliar bastón de grafito. Los electrodos de trabajo consistieron de cilindros de Ti-10Mo embutidos en polietileno, con contacto eléctrico por hilo de latón y tinta de plata en una de las extremidades. El electrolito utilizado fue $\mathrm{H}_{2} \mathrm{O}_{2}$ en concentración del $15 \%$, el $22 \%$ y el $35 \%$ y las medidas potenciodinámicas se registraron. La dureza Vickers fue evaluada antes del tratamiento utilizando penetrador Vickers bajo carga de $1000 \mathrm{~g}$ y tiempo de permanencia de 10s / medición separada. Los resultados obtenidos mostraron un aumento en los valores de corrosión en relación directa con el aumento de la concentración de $\mathrm{H}_{2} \mathrm{O}_{2}$. En la concentración de 35\%, en corriente constante de $\sim 1.0 \mathrm{~V}$ la aleación no pasivó, caracterizando alta tasa de corrosión. En las concentraciones de $15 \%$ y $22 \%$ los resultados apuntaron tendencia a la pseudopasivación, con liberación de $\mathrm{TiO} 2$ y parte del producto de la corrosión volviéndose semiadente a la superficie del electrodo de trabajo y otra parte pasando hacia el medio, caracterizando velocidad de corrosión intermedia. Se concluyó que mayores concentraciones de $\mathrm{H}_{2} \mathrm{O}_{2}$ produjeron mayor corrosión electroquímica.

Descriptores: Titanio; Aleaciones; Propiedades de Superficie; Corrosión; Blanqueadores Dentales.

\section{INTRODUCTION}

Titanium and its alloys exhibit excellent mechanical properties as well as biocompatibility. This superior behavior makes titanium alloys suitable material for use in biomedical applications ${ }^{1-5}$. In the last decades, it was particular interest to develop $\beta$ Ti-based alloys produced from non-toxic elements and that present lowest elasticity modulus and high strength such as Ti-Mo ${ }^{5-8}$.
Ho et al. ${ }^{9}$ reported that both crystalline structure and microstructures of the Ti-Mo alloy is sensitive to their molybdenum contents. They showed that molybdenum content of $10 \mathrm{wt} \%$ is sufficient for to stabilize $\beta$-phase at room temperature. Also $10 \% \mathrm{Mo}$ microstructure offers excellent ductility and strength ${ }^{8}$. All the titanium alloys containing 7.5-20 wt\% has higher values of bending 
strength and Ti-10Mo has the highest (1752 MPa). Bending strength of Ti-10Mo is twice that of c.p.Ti $(884 \mathrm{MPa})$ and little lower than Ti-6Al-4V (1860MPa) ${ }^{9}$.

It's well recognized that the release of aluminum and vanadium ions from the Ti-6Al-4V alloy might cause health problems, such as neurologic disorders and osteomalacia ${ }^{10}$. The development of non-toxic element $\beta$-type $\mathrm{Ti}$ alloys, such as Ti-Mo ${ }^{6,8,11}$, Ti-Nb ${ }^{12-14}, \mathrm{Ti}^{-Z^{15}}$ and $\mathrm{Ti}^{-\mathrm{Ta}^{16-18}}$ had been increased.

To further develop the potential properties and promising applications Ti-10Mo alloy, in our previous study, we investigated the effect of commercial mouthwashes on the corrosion resistance and found that protective characteristics of this passive film are lower in fluoride mouthwashes ${ }^{1}$. The dissolution of the $\mathrm{TiO}_{2}$ film may occur due oral electrolytic environmental conditions and could affect properties of materials such as microhardness ${ }^{1,19}$.

These conditions include tooth bleaching, one the most popular treatment on esthetic dentistry. Since 1989, the beginning of the teeth whitening idea ${ }^{20}$ there was a rapid increase of the demand for dental whitening to satisfy high patient expectations, driven strongly by an enhanced awareness of beauty and esthetics ${ }^{21}$. There are many techniques available for this procedure such as in-office bleaching, at-home use of bleaching trays, strip-based materials, or a combination of the treatment methods ${ }^{22}$. Hydrogen peroxide (HP) is the active agent in-office dental bleaching materials ${ }^{22,23}$. Also is used combined with urea to form carbamide peroxide which it is applied in the at-home bleaching option. In an aqueous environmental the carbamide peroxide decomposes to release hydrogen peroxide: $10 \%$ carbamide peroxide yields roughly $3.5 \%$ hydrogen peroxide. High hydrogen peroxide concentration has been used as in-office bleaching materials (typically 20$38 \%$ ) for whitening of vital teeth ${ }^{23}$. Investigators report adverse effects of bleaching on dental materials according treatment method and type or concentration of the active agent (hydrogen peroxide or carbamide peroxide). Al-Salehi et al. ${ }^{25}$ founded that metal ion release from the $\mathrm{Ni}-\mathrm{Cr}$ and $\mathrm{Pd}-\mathrm{Cu}-\mathrm{Ga}$ alloys increased with increasing hydrogen peroxide concentration (0 to 30\%). Similar results founded at nickel-chromium dental alloys ${ }^{26}$. Takemoto et al. ${ }^{27}$ believe that discoloration in titanium alloys (Ti-Pd, Ti-Al$\mathrm{V}$, Ti-Al-Nb, Ti-Ni, Ti-Cu and Ti-Cr) immersed in hydrogen peroxide-containing acidulated solutions is caused by an increase in the thickness of this oxide film, whereas discoloration of Ti-Ni is caused by corrosion.

In this study, the microhardness and corrosion behavior of experimental Ti-710Mo alloy in-office dental bleaching agents have been investigated.

\section{MATERIAL AND METHOD}

The Ti-Mo alloy with 10 wt.\% Mo was made by melting of commercially pure titanium (c.p.Ti) grade 1 and commercially pure molybdenum (99.9\%) into one $15 \mathrm{~g}$ button $(\sim 1.3 \mathrm{~cm}$ diameter and $\sim 2.6 \mathrm{~cm}$ length) in an argonarc melting furnace. The ingots were remelted ten times in order to improve chemical homogeneity.

Cylinders (with cross-section of $1 \mathrm{~cm}^{2}$ ) were machined from ingots of Ti-Mo experimental alloy. These cylinders and c.p.Ti discs with $1.1 \mathrm{~cm}$ diameter were mounted in polyester resin and employed as working electrodes. Before each experiment, working electrodes were ground with 600 and 1200 grade emery papers, rinsed with distilled water and dried in air. The counter electrode was a platinum wire and reference electrode was an $\mathrm{Ag} / \mathrm{AgCl}, \mathrm{KCl}$ saturated electrode. The open circuit potential measurements, potentiodynamic and chronoamperometric curves were performed by means of an EG\&G PAR Potentiostat/Galvanostat Model 283 (PerkinElmer Instruments Inc., USA). The conventional three-compartment double wall glass cell was connected to a constant temperature circulator operating at $37 \pm 0.5^{\circ} \mathrm{C}$ to simulate mouth conditions The test solutions used in this study were the dental office bleaching agents: $15 \%$ hydrogen peroxide $\left(\mathrm{H}_{2} \mathrm{O}_{2}\right)$, $22 \%$ hydrogen peroxide $\left(\mathrm{H}_{2} \mathrm{O}_{2}\right)$ and $35 \%$ hydrogen peroxide $\left(\mathrm{H}_{2} \mathrm{O}_{2}\right)$. The assessment of individual effect of active ingredient was studied by using $0.05 \%$ sodium fluoride $\mathrm{pH}=6.0$. Corrosion behavior was studied in naturally aerated conditions. Open circuit potential measurements were recorded during an immersion time of $8 \mathrm{~h}$. Potentiodynamic polarization curves were recorded in electropositive direction at a sweep rate of 0.02 $\mathrm{V} / \mathrm{min}$ starting from $-1.00 \mathrm{~V}$ up to $2.50 \mathrm{~V}$.

Vickers hardness measurements were recorded on Ti-10Mo disks(n=5) using a MHT-1 microhardness tester equipped with a Vickers indenter under a load of $1000 \mathrm{~g}$ and with a dwell time of 10 s for each separate measurement (Digital Microhardness Tester HMV-2T, Shimadzu, Japan). All values of the Vickers microhardness $(\mathrm{Hv})$ were recorded along a randomly selected diameter of each disk. For be obtained a high degree of accuracy, the average values of $\mathrm{Hv}$ were determined at selected positions separated incrementally by distances of $0.3 \mathrm{~mm}$ along each diameter. At every point the average value of $\mathrm{Hv}$ was achieved from six separate hardness measurements recorded at points uniformly arrayed around the selected position and separated from this position by distances of $0.15 \mathrm{~mm}$. These six separate measurements were used also to estimate the 95\% error bars for each separate point. Vicker hardness measurements on c.p.Ti $(\mathrm{n}=5)$ discs were obtained for comparative analysis.

\section{RESULTS}

Vicker's microhardness measures were performed before corrosion behavior test. The hardness values for Ti-10Mo alloy samples were significantly higher $(229,08 \pm$ $3,39)$ than pure titanium $(187 \pm 4)$, resulting from the solid solution hardening caused by the addition of molybdenum having a higher atomic mass than titanium.

The results of corrosion test show that the value of the open circuit potential tends to be more positive when the electrolyte concentration is higher. This can be explained by the fact that more concentrated solutions of hydrogen peroxide produce more stable species on the alloy surface or that such values are due to the variation of the electrolyte concentration over the Ti-Mo in the medium.

Figure 1 shows the curves obtained for Ti-10Mo immersed in hydrogen peroxide solution at the three naturally aerated study concentrations at $37^{\circ} \mathrm{C}$. Through this technique it was possible to determine the corrosion potential, which corresponds to the stabilization potential of the system.

It is observed that after 7 hours of immersion the potential is almost constant and corresponds to the potential provided by the spontaneous reactions that occur in the surface of the material in the electrolyte under study. In general, at the initial test time, a slight shift of the potential to nobler values occurs, and then a decrease of that potential, reaching a more negative value. Note that the titanium alloy in the $\mathrm{H}_{2} \mathrm{O}_{2}$ solution at either $15 \%, 22 \%$ or 
$35 \%$ concentration achieves stability after about 60 minutes of immersion.

In the first few minutes of immersion, the increase in open circuit potential may be associated with the decrease of the active area of the electrode by the growth of an oxide film on the alloy surface due to the oxidizing properties of the medium. The presence of compact films and insulation prevents the process of corrosion of the material, as they act as a barrier, making the material passive in the study medium. The result is an increase in the potential of the system. In the specific case of the Ti10Mo alloy in $\mathrm{H}_{2} \mathrm{O}_{2}$, the decrease of the potential in the first 60 minutes indicates that the film formed on the electrode is not very protective. The dissolution of the oxide or formed oxides and less noble constituents of the alloy results in the decrease of the potential and the stabilization thereof in values more negative than that of the instant of immersion of the electrode in the solution. The stabilization potential corresponds to the equilibrium potential of the species involved in the corrosion process.

The results show that the value of the open circuit potential tends to be more positive when the electrolyte concentration is higher. This can be explained by the fact that more concentrated solutions of hydrogen peroxide produce more stable species on the alloy surface or that such values are due to the variation of the electrolyte concentration over the Ti10Mo in the medium.

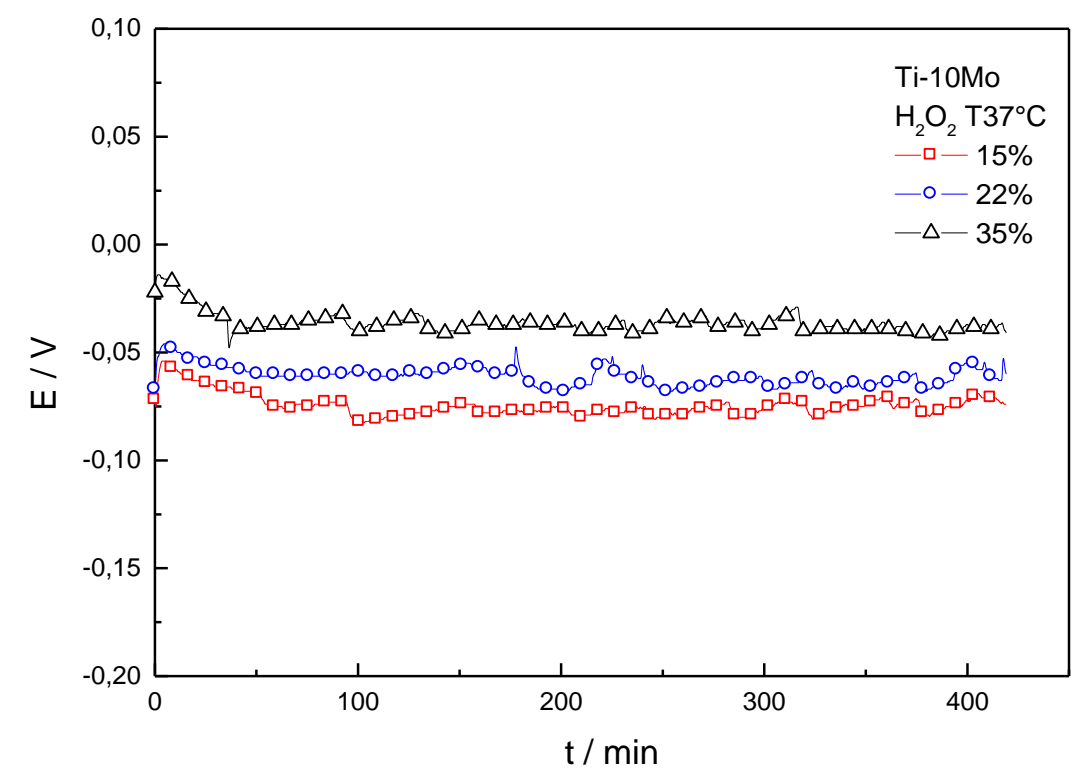

Figure 1: Potential measurements in open circuit with time for alloy in $\mathrm{H}_{2} \mathrm{O}_{2}$ medium with different concentrations.

Figure 2 shows the results of the anodic potentiodynamic polarization tests obtained in $15 \%, 22 \%$ and $35 \%$ hydrogen peroxide solution performed immediately after 7 hours of open circuit immersion. It can be observed that the Ti-10Mo alloy in $15 \% \mathrm{H}_{2} \mathrm{O}_{2}$ solution has a current shoulder located at approximately $+0.64 \mathrm{~V}$, followed by a decrease in current, revealing a tendency to passivation of the material. When the potential reaches values greater than $1.2 \mathrm{~V}$ the current showed increases again. This behavior is typical of a pseudopassive material, that is, the formed film is not very protective and even before the occurrence of passivation the rupture of the film occurs. The high current value indicates the presence of a porous film. The behavior of the alloy in $22 \% \mathrm{H}_{2} \mathrm{O}_{2}$ solution is similar. The oxidation current shoulder shifted to about + $0.74 \mathrm{~V}$ and the current decrease observed after the current shoulder is less pronounced. In $35 \% \mathrm{H}_{2} \mathrm{O}_{2}$ solution there is practically no current shoulder but only an increase in current reaching a constant value of approximately $+1.0 \mathrm{~V}$. The current value is quite high about $1.1 \mathrm{~A} \mathrm{~cm}-2$. This behavior shows that in the range of hydrogen peroxide concentration studied the non-passive alloy. The displacement of the potential corresponding to current maxima; high values of anodic current indicate the participation of the electrolyte in the oxidation process and probably the presence of poor protective and porous films.

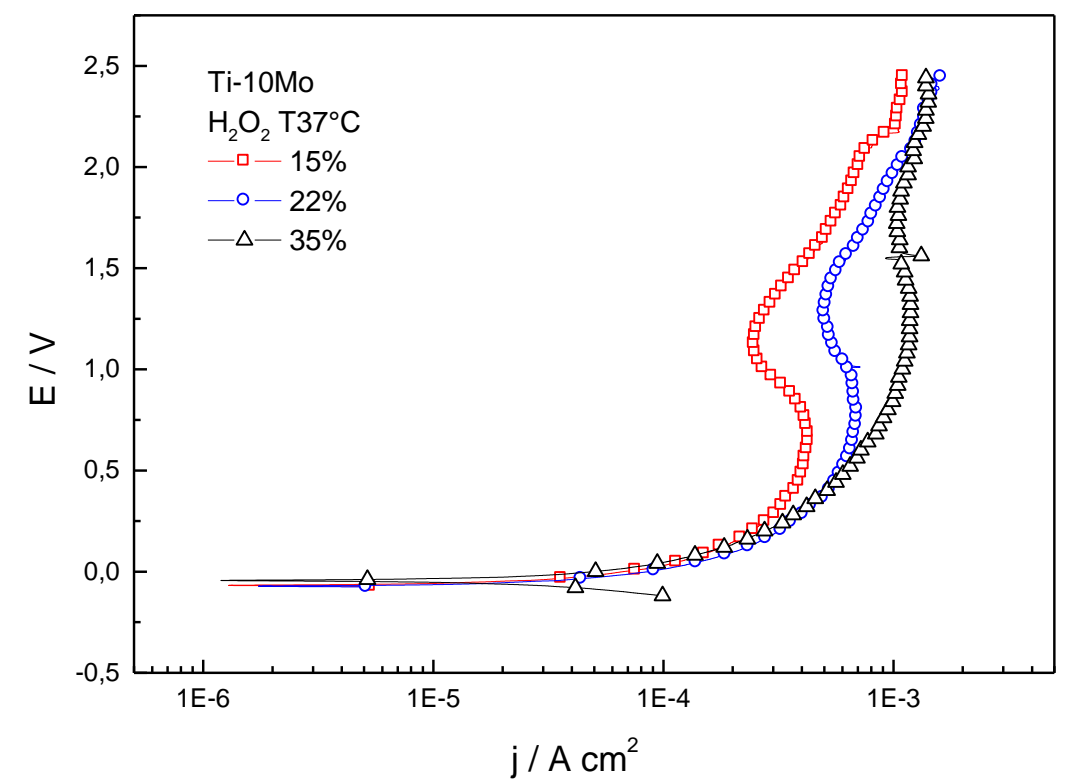

Figure 2: Anodic potentiodynamic polarization tests obtained in $15 \%$, $22 \%$ and $35 \%$ hydrogen peroxide solution performed immediately after 7 hours of open circuit immersion.

In Figure 3 the potentiodynamic polarization curves of the alloy in naturally aerated $\mathrm{H}_{2} \mathrm{O}_{2}$ solution were recorded at $0.020 \mathrm{~V} / \mathrm{min}$, with scanning starting at the cathode region, about $-0.40 \mathrm{~V}$ below potential corrosion, in the potential directions positive. The cathodic region exhibits a current density where no limiting oxygen reduction current is observed at any of the concentrations under study. An increase in the cathodic current is observed clearly with the increase of the concentration of hydrogen peroxide. The Ti$10 \mathrm{Mo}$ alloy in the presence of $35 \% \mathrm{H}_{2} \mathrm{O}_{2}$ shows a higher cathodic current density, which is considerably high $(\sim 10-3$ A cm-2). For the $15 \%$ and $22 \% \mathrm{H}_{2} \mathrm{O}_{2}$ solutions the current density is lower (about 10-4 A cm-2). This result confirms what was mentioned previously where the observed behavior can be attributed to the reduction of the electrolyte on the electrode. In the anodic region the behavior is analogous to that observed for the anodic curves obtained from the corrosion potential. When the tests are performed in a less concentrated solution of $\mathrm{H}_{2} \mathrm{O}_{2}$, the formation of less protective oxide can be observed.

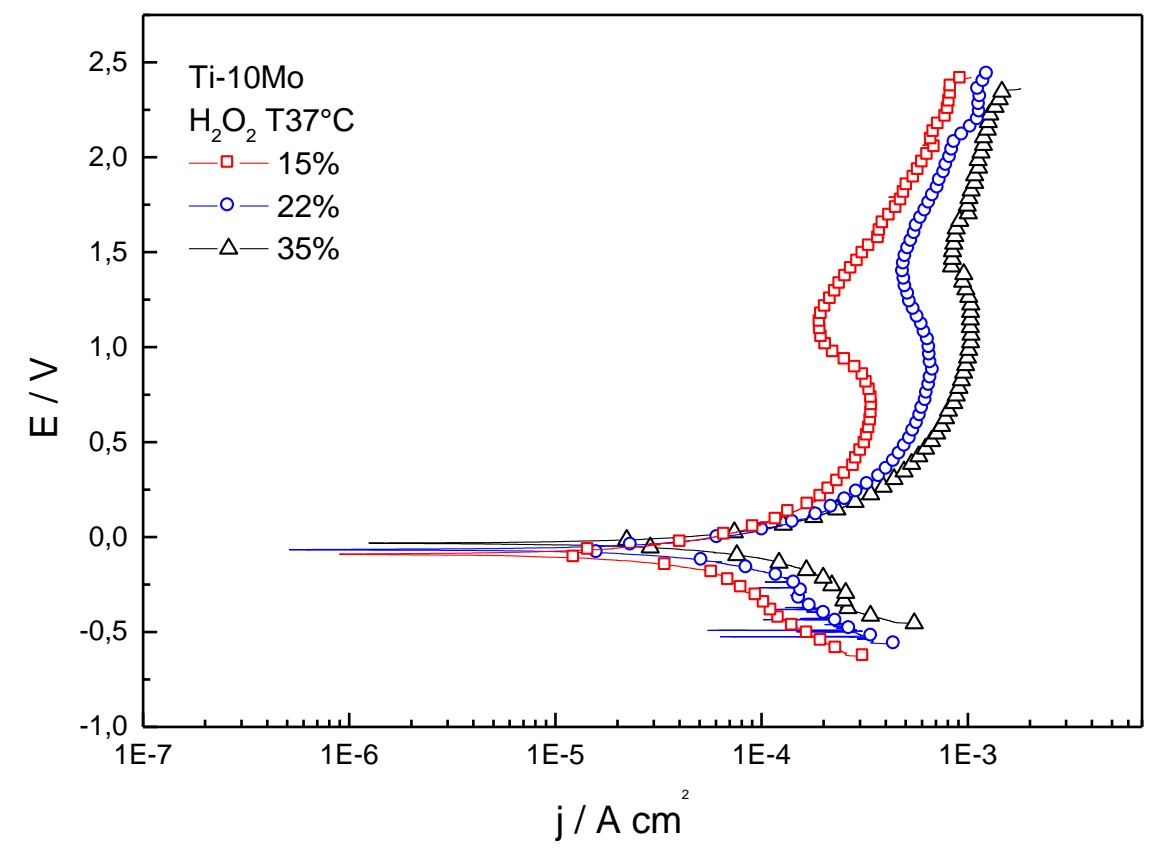

Figure 3: Potentiodynamic polarization curves of the alloy in naturally aerated $\mathrm{H}_{2} \mathrm{O}_{2}$ solution at $0.020 \mathrm{~V} / \mathrm{min}$.

A c.p.Ti polarization curve for comparison is shown in Figure 4. When the behavior of Ti10Mo and c.p.Ti in $22 \% \mathrm{H}_{2} \mathrm{O}_{2}$ solution is compared, the presence of maximum 
current, which can be attributed to the formation of an oxide film on the metal, is also verified in the anodic region. However the observed current is lower, which shows changes in the properties of the titanium oxide film formed from pure $\mathrm{Ti}$ and the Ti-10Mo alloy. As the current value for the alloy is higher, this may indicate the formation of film less protective than that formed from pure $\mathrm{Ti}$ or catalytic effect of molybdenum on the oxidation of hydrogen peroxide.

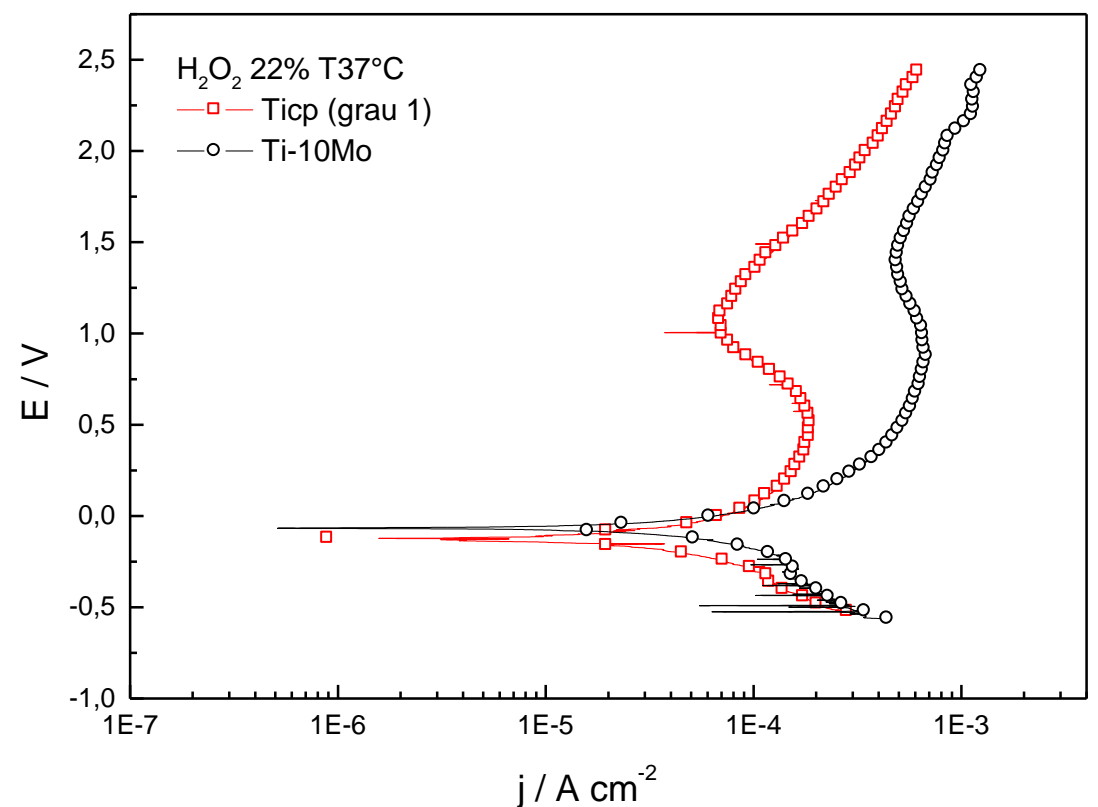

Figure 4: Potentiodynamic polarization curves for c.p.Ti (grade 1) and Ti-10Mo alloy in $22 \% \mathrm{H} 2 \mathrm{O} 2$ solution at $\mathrm{T} 37^{\circ} \mathrm{C}$.

Table 1 presents the values of corrosion potentials and current density obtained at constant potential value $(+0.70 \mathrm{~V})$ for Ti-10Mo alloy in the three media under study.

Table 1. Values of corrosion potentials and current density obtained

\begin{tabular}{|c|c|c|}
\hline \multicolumn{3}{|c|}{ Ti-10Mo } \\
\hline $\mathbf{H}_{\mathbf{2}} \mathbf{O}_{\mathbf{2}}$ & $\mathbf{E}_{\text {corr }} \mathbf{( V )}$ & $\mathbf{j}\left(\mathbf{A ~ c m}^{-2}\right)$ \\
\hline $15 \%$ & $-0,78$ & $3,5 \times 10^{-4}$ \\
\hline $22 \%$ & $-0,62$ & $6,7 \times 10^{-4}$ \\
\hline $35 \%$ & $-0,33$ & $1,1 \times 10^{-3}$ \\
\hline
\end{tabular}

Figure 5 shows the surface of Ti10Mo before corrosion test with peroxide hydrogen solutions. Figures 6-8 exhibit the surface of Ti10Mo after corrosion behavior $\mathrm{H}_{2} \mathrm{O}_{2}$ at $22 \%$, the best result among three peroxide hydrogen solutions.

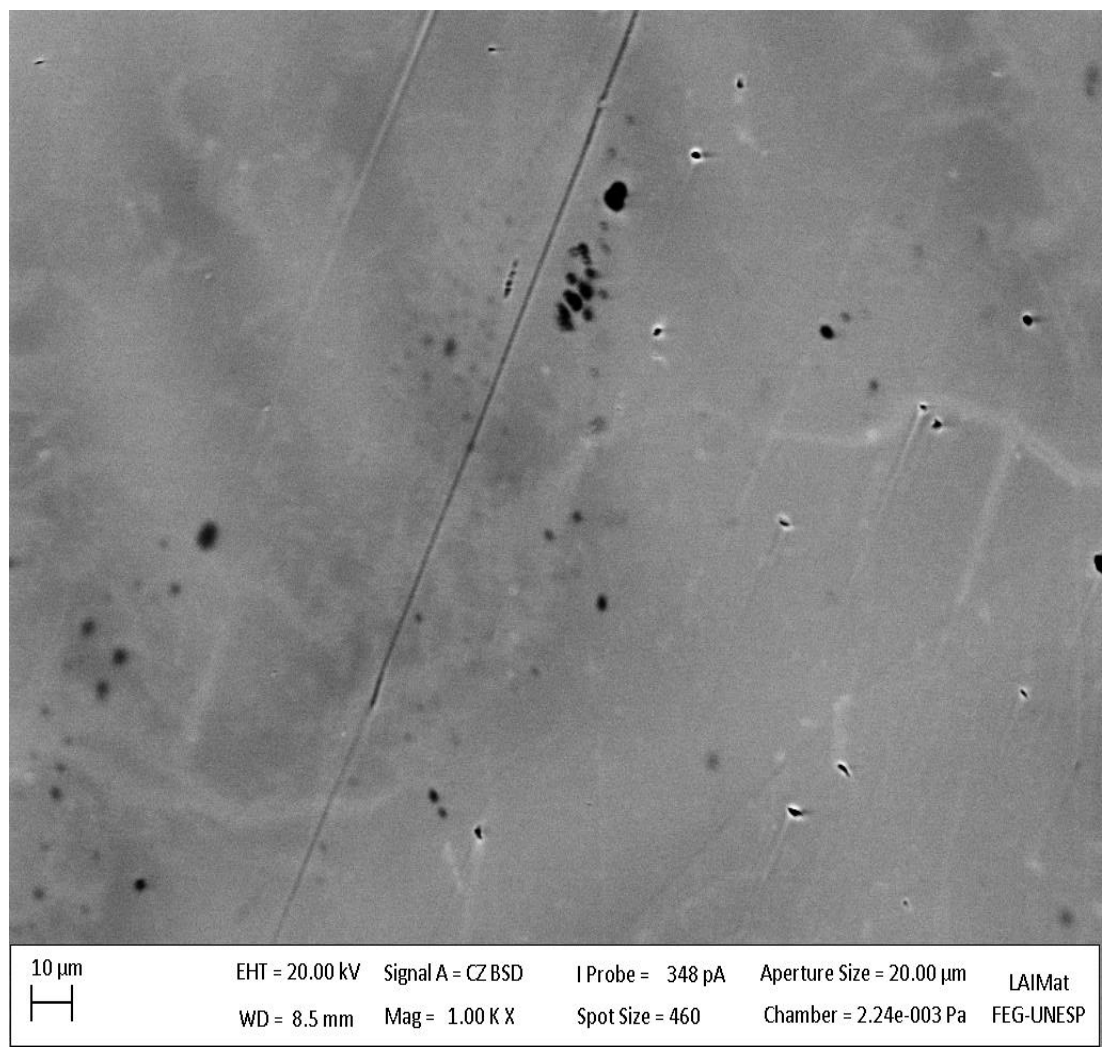

Figure 5: Surface of Ti10Mo before corrosion test

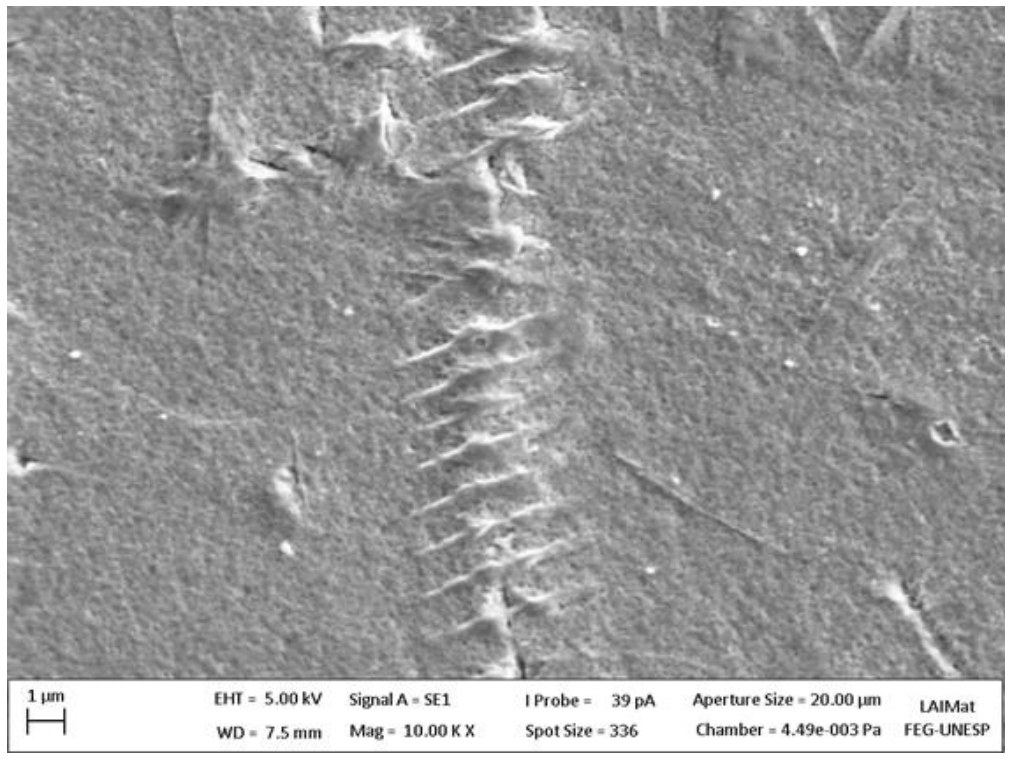

Figure 6: Surface of Ti10Mo after corrosion behavior $\mathrm{H}_{2} \mathrm{O}_{2}$ at $22 \%$

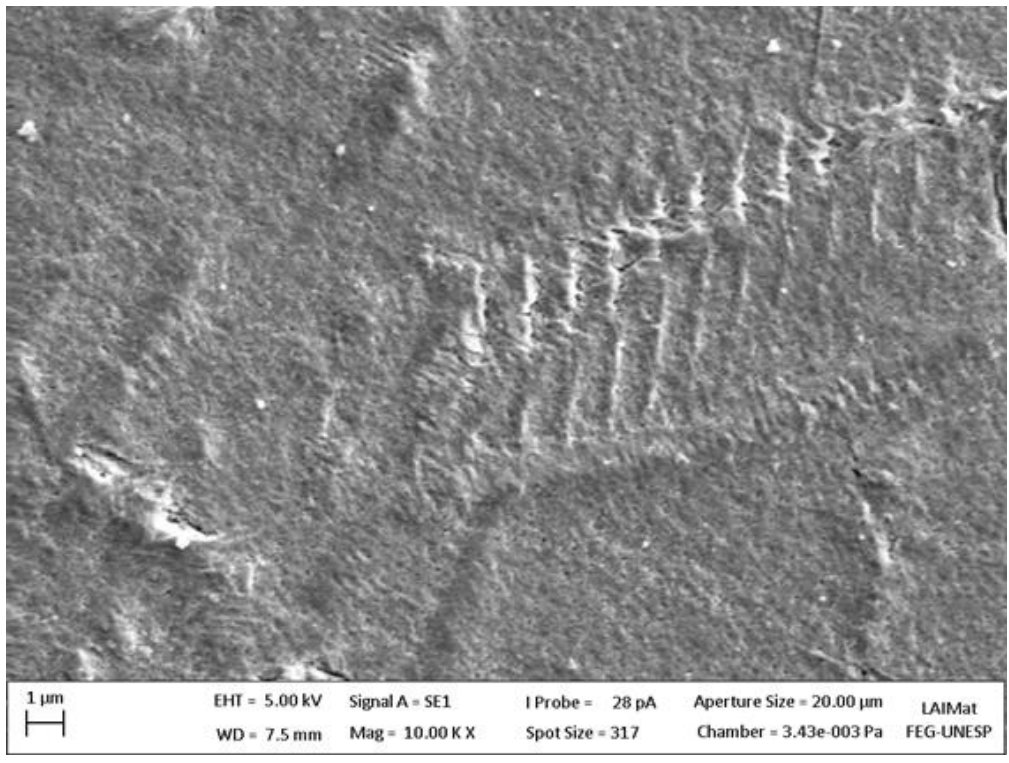

Figure 7: Surface of Ti10Mo after corrosion behavior $\mathrm{H}_{2} \mathrm{O}_{2}$ at $22 \%$.

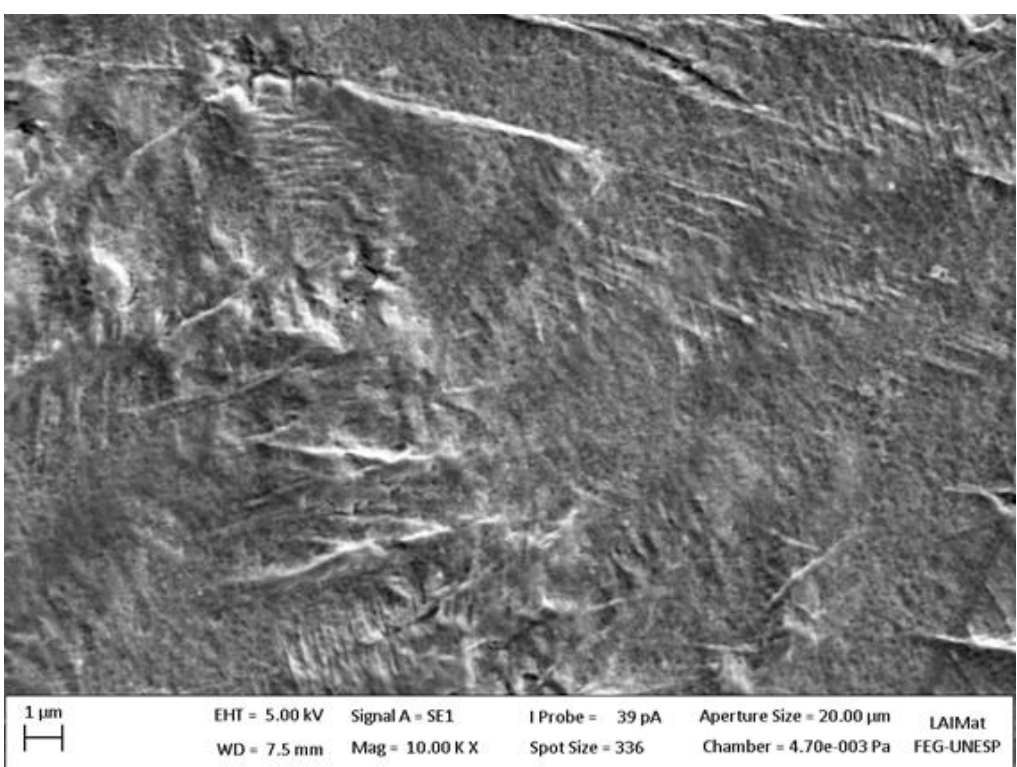

Figure 8: Surface of Ti10Mo after corrosion behavior $\mathrm{H}_{2} \mathrm{O}_{2}$ at $22 \%$.

\section{DISCUSSION}

The performance of $\mathrm{Ti}$ alloys intended to be used in orthopedic and dental devices is generally examined by mechanical and biological properties ${ }^{28}$.

In the present paper, Vickers hardness means of $\mathrm{Ti}$ 10Mo was remarkably higher than that of the c.p. Ti which was attributed to the decreased grain size and the solid solution effect of alloying elements. It is know that the increase in Vickers hardness decreases the incidence of wear of biomedical material ${ }^{29}$. The results obtained were agreeing with results found by Ho et al. ${ }^{9}$ that investigated structure and properties of a series of binary Ti-Mo alloys with molybdenum contents ranging from 6 to $20 \mathrm{wt} \%$.

Although several studies have evaluated the effects of bleaching agents on the physicochemical properties of 
restorative materials, few investigators have studied the corrosion of titanium alloys when exposed to these products.

Takemoto et al. ${ }^{27}$ suggest that although titanium has high resistance to corrosion, during clinical behavior in the oral environment it may experiment dissolution due to contact with oral rinses or bleaching agents.

In the present paper, the values of the corrosion resistance exhibited by Ti-10Mo alloy suffer a direct effect of the hydrogen peroxide concentration. So, it is possible affirm that $\mathrm{Er}$ and $\mathrm{Ev}$ decreased with increasing concentration of hydrogen peroxide.

Results similar to those found in the present work were observed by Assis ${ }^{30}$, which investigated the corrosion resistance of titanium alloy containing $13 \%$ of neobium and $13 \%$ of zirconium in a hydrogen peroxide-containing environment. For this author, the formation of passive porous layer on the surface of the alloy allows to conclude that the resistance to corrosion can be explained by the type of layer or barrier that forms on the surface of the alloy.

Noguchi et al. ${ }^{31}$ compared differences in discoloration and dissolution between commercially pure titanium alloy (c.p.Ti) and six titanium based alloys when immersed in hydrogen peroxide or fluoride solution. Their results showed that titanium associated with $20 \%$ chromium reached the lowest values for discoloration and dissolution.

Mohsen $^{32}$ studied the effect of bleaching agents (home use and dental office products) on the surface topography of three ceramometal dental alloys (gold, Ni-Cr, Co-Cr-Ti). Scanning electron microscopy revealed surface topographic alterations for all tested alloys in presence of both bleaching agents. The increased concentration of hydrogen peroxide led to increased surface roughness.

Takemoto et al. $^{27}$ investigated discoloration of commercially pure titanium, Ti-Pd, Ti-Al-V, Ti-Al-Nb, Ti$\mathrm{Ni}, \mathrm{Ti}-\mathrm{Cu}$ and $\mathrm{Ti}-\mathrm{Cr}$ alloys in acidic saline solutions with hydrogen peroxide. Their results suggest that discoloration in titanium alloys immersed in hydrogen peroxidecontaining acidulated solutions is caused by an increase in the thickness of this oxide film, whereas discoloration of Ti-Ni is caused by corrosion.

Nakamura et al. ${ }^{33}$ evaluated the corrosive effect of disinfection solution containing hydroxyl radicals generated by photolysis of $\mathrm{H}_{2} \mathrm{O}_{2}$ on dental metals (Ti, Type 316L stainless steel, Ag-Pd-Cu-Au alloy and $\mathrm{Co}-\mathrm{Cr}$ alloy) and observed that hydrogen peroxide can be applied to denture cleaning device without problematic metal corrosion unless the dentures contain $\mathrm{Ti}$ components.

Yokoyama et al. ${ }^{34}$ suggested that localized corrosion of Ni-Ti alloy due to the synergistic effects of hydrogen peroxide and sodium chloride promotes fracture in vivo under stress.

Xie et al. ${ }^{35}$ studied the influence of additives $(\mathrm{K}+$, $\left.\mathrm{Ca}^{2+}, \mathrm{Na}+, \mathrm{Mg}^{2+}, \mathrm{Cl}-, \mathrm{HPO} 4^{2-}, \mathrm{H}_{2} \mathrm{PO}^{2-}\right)$ on corrosion behavior of titanium in hydrogen peroxide solutions using spectrophotometer. They concluded that The results indicated that $\mathrm{Ca}^{2+}$ exhibited the highest inhibition to the titanium corrosion in hydrogen peroxide solutions, while $\mathrm{H}_{2} \mathrm{PO}^{2-}$ behaved as an accelerator to the corrosion.

The detrimental effect of bleaching agents on the passivation process of $\mathrm{Ti}-10 \mathrm{Mo}$ alloy observed in present study plays important influence on the dental device longevity. The corrosion can compromised the mechanical properties of titanium alloys and they might deleterious effects in tissues or cumulative effects in the body.

\section{CONCLUSION}

Within the limits of this study, it may be concluded that values of Vickers hardness found for Ti-10Mo was higher than that of the c.p.Ti which suggests the better clinical performance of alloy. The corrosion values showed direct relation with the increase of the $\mathrm{H}_{2} \mathrm{O}_{2}$ concentration.

\section{REFERENCES}

1. Alves Rezende MC, Alves AP, Codaro EN, Dutra CA. Effect of commercial mouthwashes on the corrosion resistance of Ti-10Mo experimental alloy. J Mater Sci Mater Med. 2007;18(1):149-54.

2. de Oliveira JA, do Amaral Escada AL, Alves Rezende MC, Mathor MB, Alves Claro AP. Analysis of the effects of irradiation in osseointegrated dental implants. Clin Oral Implants_Res. 2012;23(4):511-4.

3. Escada AL, Machado JP, Schneider SG, Rezende MC, Claro AP. Biomimetic calcium phosphate coating on Ti-7.5Mo alloy for dental application. J Mater Sci Mater Med. 2011; 22(11):2457-65.

4. Narita K, Niinomi M, Nakai M. Effects of micro- and nano-scale wave-like structures on fatigue strength of a beta-type titanium alloy developed as a biomaterial. J Mech Behav Biomed Mater. 2014;29:393-402.

5. Niinomi M. Fatigue performance and cyto-toxicity of low rigidity titanium alloy, $\mathrm{Ti}-29 \mathrm{Nb}-13 \mathrm{Ta}-4.6 \mathrm{Zr}$. Biomaterials. 2003;24(16):2673-83.

6. Oliveira NT, Guastaldi FP, Perrotti V, Hochuli-Vieira E, Guastaldi AC, Piattelli A, Iezzi G. Biomedical TiMo alloys with surface machined and modified by laser beam: biomechanical, histological, and histometric analysis in rabbits. Clin Implant Dent Relat Res. 2013;15(3):427-37.

7. Zhou YL, Luo DM. Microstructure and mechanical properties of Ti-Mo alloys cold-rolled and heat treated. Mater. Charact. 2011; 62, 931-37.

8. Oliveira NTC, Aleixo G, Caram R, Guastaldi AC. Development of Ti-Mo alloys for biomedical applications: microstructure and electrochemical characterization. Mater Sci Eng A. 2007: 452-3,727-31.

9. Ho WF, Ju CP, Lin JH. Structure and properties of cast binary Ti-Mo alloys. Biomaterials. 1999; 20(22):211522.

10. Serra G, Morais L, Elias CN, Semenova IP, Valiev R, Salimgareeva G, Pithon M, Lacerda R. Nanostructured severe plastic deformation processed titanium for orthodontic mini-implants. Mater Sci Eng C Mater Biol Appl. 2013; 33(7):4197-202.

11. Cardoso FF, Ferrandini PL, Lopes ES, Cremasco A, Caram R. Ti-Mo alloys employed as biomaterials: Effects of composition and aging heat treatment on microstructure and mechanical behavior. J Mech Behav Biomed Mater. 2013; 32C:31-8.

12. Tane M, Akita S, Nakano T, Hagihara K, Umakoshi Y, Niinomi $\mathrm{M}$ et al. Peculiar Elastic Behavior of Ti-NbTa-Zr Single Crystals. Acta Mater. 2008; 56: 2856-63.

13. Jung TK, Semboshi S, Masahashi N, Hanada S. Mechanical properties and microstructures of $\quad \beta$ Ti$25 \mathrm{Nb} 11 \mathrm{Sn}$ ternary alloy for biomedical applications. Mater Sci Eng C Mater Biol Appl. 2013 ;33(3):162935.

14. Guo Y, Chen D, Lu W, Jia Y, Wang L, Zhang X. Corrosion resistance and in vitro response of a novel Ti35Nb2Ta3Zr alloy with a low Young's modulus. Biomed Mater. 2013; 8(5):055004. 
15. Correa DR, Vicente FB, Donato TA, Arana-Chavez VE, Buzalaf MA, Grandini CR. The effect of the solute on the structure, selected mechanical properties, and biocompatibility of Ti-Zr system alloys for dental applications. Mater Sci Eng C Mater Biol Appl. 2014; 34:354-9.

16. Gill P, Munroe N, Pulletikurthi C, Pandya S, Haider W. Effect of manufacturing process onthe biocompatibility and mechanical properties of Ti30Ta alloy. J Mater Eng Perform. 2011; 20(4):819-23.

17. Alves Rezende MCR, Capalbo BC, Louzada MJQ, Rangel ALR, Cintra LA, Oliveira JAG, Lisboa Filho PN, Wada CM, Alves Claro APR. Osseointegration of Ti-30Ta implants without primary stability: effect of tranexamic acid. Mater Sci Forum. 2016;869:918-23.

18. Wada CM, Rangel ALR, Souza MA, Almeida RS, D’Avila MA, Alves Claro APR, Alves Rezende MCR. Surface Modification of Ti-30Ta Alloy by Electrospun PCL Deposition. Mater Sci Forum. 2016;869:930-4.

19. Fais LM, Fernandes-Filho RB, Pereira-da-Silva MA, Vaz LG, Adabo GL. Titanium surface topography after brushing with fluoride and flouride free toothpaste simulating 10 years of use. J Dent. 2012; 40(4):265-75.

20. Haywood VB, Heymann HO. Nightguard vital bleaching. Quintessence Int. 1989; 20(3):173-6.

21. Singh VP, Uppoor AS, Nayak DG, Shah D. Black triangle dilemma and its management in esthetic dentistry. Dent Res J (Isfahan). 2013; 10(3):296-301.

22. Wang W, Zhu Y, Li J, Liao S, Ai H. Efficacy of cold light bleaching using different bleaching times and their effects on human enamel. Dent Mater J. 2013; 32(5): 761-6.

23. Basson RA, Grobler SR, Kotze TJ, Osman Y. Guidelines for the selection of tooth whitening products amongst those available on the market. SADJ. 2013; 68(3):122-9.

24. Alonso De La Peña V, Rodriguez Carreira A, Corral Aneiros R, López Ratón M, Guitián Rivera F. A study of in vivo degradation of two vital home bleaching gels. Dent Mater J. 2013; 32(4): 654-58.

25. Al-Salehi SK, Hatton PV,Johnson A, Cox AG, McLeod C. The effect of hydrogen peroxide concentration on metal ion release from dental casting alloys. J Oral Rehabil. 2008 ; 35(4):276-82.

26. Wang J, Qiao GY. The effect of hydrogen peroxide on the electrochemical corrosion properties and metal ions release of nickel-chromium dental alloys. Shanghai Kou Qiang Yi Xue. 2013; 22(2):137-41.

27. Takemoto S, Hattori M, Yoshinari M, Kawada E, Oda Y. Discoloration of titanium alloy in acidic saline solutions with peroxide. Dent Mater J. 2013; 32(1):19-24.

28. Rosa JL, Nakazato RZ, Scheneider SG, Alves Claro APR, Alves Rezende MCR. Wettability behavior of nanotubular $\mathrm{TiO} 2$ intended for biomedical applications. Arch Health Invest. 2014; 3(5):43-7.

29. Saini M, Singh Y, Arora P, Arora V, Jain K. Implant biomaterials: A comprehensive review. World J Clin Cases. 2015; 3(1): 52-7.

30. Assis Assis SL, Wolynec S, Costa I. Corrosion characterization of titanium alloys by electrochemical techniques. Electrochimica Acta. 2006; 51:1815-9.

31. Noguchi T, Takemoto S, Hatton M, Yoshinari M, Kawada E, Oday Y. Discoloration and dissolution of titanium and titanium alloys with immersion in peroxide- or fluoride-containing solutions. 2008; 27(1):117-23.

32. Mohsen CA. The effect of bleaching agents on the surface topography of ceramometal dental alloys. J Prosthodont. 2010; 19(1):33-41.

33. Nakamura K, Yamada Y, Takada Y, Mokudai T, Ikai $\mathrm{H}$, Inagaki $\mathrm{R}$ et al. Corrosive effect of disinfection solution containing hydroxyl radicals generated by photolysis of $\mathrm{H} 2 \mathrm{O} 2$ on dental metals. Dental Mater J. 2012; 31(6):941-6

34. Yokoyama K, Ogawa T, Fujita A, Asaoka K, Sakai J. Fracture of $\mathrm{Ni}-\mathrm{Ti}$ superelastic alloy under sustained tensile load in physiological saline solution containing hydrogen peroxide. J Biomed Mater Res A. 2007; 82(3):558-67.

35. Xie L, Wang XX, Li J. The corrosion behavior of titanium in hydrogen peroxide solution with various additives. Key Engineer Mater. 2007; 330332(19):1285-88.

\section{CONFLICTS OF INTERESTS}

The authors declare no conflicts of interests.

\section{CORRESPONDING AUTHOR}

Maria Cristina Rosifini Alves Rezende

rezende@foa.unesp.br

Received 31/08/2017 Accepted 04/10/2017 